\title{
Efficiency of Indian Banking Industry in the Post-Reform Era
}

\author{
Amit Kumar Dwivedi \\ D. Kumara Charyulu
}

W.P. No. 2011-03-01

March 2011

The main objective of the working paper series of the IIMA is to help faculty members, research staff and doctoral students to speedily share their research findings with professional colleagues and test their research findings at the pre-publication stage. IIMA is committed to maintain academic freedom. The opinion(s), view(s) and conclusion(s) expressed in the working paper are those of the authors and not that of IIMA.

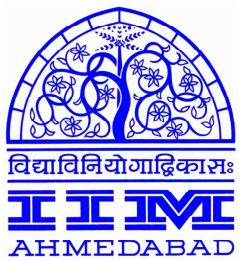

INDIAN INSTITUTE OF MANAGEMENT AHMEDABAD-380 015

INDIA 


\title{
Efficiency of Indian Banking Industry in the Post-Reform Era \\ Amit Kumar Dwivedi ${ }^{1}$ \\ D. Kumara Charyulu²
}

\begin{abstract}
One of the major objectives of Indian banking sector reforms was to encourage operational self-sufficiency, flexibility and competition in the system and to increase the banking standards in India to the international best practices. The second phase of reforms began in 1997 with aim to reorganization measures, human capital development, technological up-gradation, structural development which helped them for achieving universal benchmarks in terms of prudential norms and pre-eminent practices. This paper seeks to determine the impact of various market and regulatory initiatives on efficiency improvements of Indian banks. Efficiency of firm is measured in terms of its relative performance that is, efficiency of a firm relative to the efficiencies of firms in a sample. Data Envelopment Analysis (DEA) has used to identify banks that are on the output frontier given the various inputs at their disposal. The present study is confined only to the Constant-Return-to-Scale (CRS) assumption of decision making units (DMUs). Variable returns to scale (VRS) assumption for estimating the efficiency was not attempted. It was found from the results that national banks, new private banks and foreign banks have showed high efficiency over a period time than remaining banks.
\end{abstract}

Keywords: Efficiency measurement, banking industry and DEA.

\footnotetext{
${ }^{1}$ Academic Associate, Indian Institute of Management, Ahmedabad, India E-mail: dwivedipgdm@gmail.com

${ }^{2}$ Former Post-Doctoral Fellow, Indian Institute of Management, Ahmedabad, India Email: kumaracharya@gmail.com
} 


\section{Introduction}

Indian banking industry, the backbone of the country's economy, has always played a key role in prevention the economic catastrophe from reaching terrible volume in the country. It has achieved enormous appreciation for its strength, particularly in the wake of the worldwide economic disasters, which pressed its worldwide counterparts to the edge of fall down. If we compare the business of top three banks in total assets and in terms of return on assets, the Indian banking system is among the healthier performers in the world. This sector is tremendously competitive and recorded as growing in the right trend (Ram Mohan, 2008). Indian banking industry has increased its total assets more than five times between March 2000 and March 2010, i.e., US $\$ 250$ billion to more than US $\$ 1.3$ trillion. This industry recorded CAGR growth of 18 percent as compared to country's average GDP growth of 7.2 percent during the same period. The commercial banking assets to GDP ratio has increased to nearly 100 percent while the ratio of bank's business to GDP has recorded nearly twofold, from 68 percent to 135 percent. The overall development has been lucrative with enhancement in banking industry efficiency and productivity. It should be underlined here is financial turmoil which hit the western economies in 2008 and the distress effect widened to the majority of the other countries but Indian banking system survived with the distress and showed the stable performance. Indian banks have remained flexible even throughout the height of the sub-prime catastrophe and the subsequent financial turmoil.

The Indian banking industry is measured as a flourishing and the secure in the banking world. The country's economy growth rate by over 9 percent since last several years and that has made it regarded as the next economic power in the world. Our banking industry is a mixture of public, private and foreign ownerships. The major dominance of commercial banks can be easily found in Indian banking, although the co-operative and regional rural banks have little business segment.

The Indian banking sector has two kinds of scheduled banks i.e. scheduled commercial banks and scheduled co-operative banks. Under the first category of 
scheduled banks, four types of entities have found based on their establishments and legal obligations. They are:

i) Public banks $(28)^{3}$,

ii) Private Banks (25),

iii) Foreign Banks working in India (29) and

iv) Regional Rural Banks (91)

The second category of scheduled cooperative banks consists of:

i) Scheduled Urban Co-operative banks (55) and

ii) Scheduled State Co-operative Banks (16)

Under public \& private sector, banks are more clearly defined according to nationalization and privatization. The banks under public banks are Nationalized Banks (20) and State Banks of India (with its associates, the number is come to 8). Under Private Bank category, banks are divided into two types i.e., Old private banks (17) and New-private banks (8).

\section{Reforms and Banking system}

In the post liberalization-era, Reserve Bank of India (RBI) has initiated quite a few measures to ensure safety and consistency of the banking system in the country and at the same point in time to support banks to play an effective role in accelerating the economic growth process. One of the major objectives of Indian banking sector reforms was to encourage operational self-sufficiency, flexibility and competition in the system and to increase the banking standards in India to the international best practices ${ }^{4}$. Although the Indian banks have contributed much in the Indian economy, certain weaknesses, i.e. turn down in efficiency and erosion in profitability had developed in the system, observance in view these conditions, the Committee on Financial System ${ }^{5}$ (CFS) was lay down.

\footnotetext{
${ }^{3}$ The number in brackets are No. of the Banks exists in that type.

4 Dr. Y.V. Reddy (2002), "Monetary and Financial Sector Reforms in India: A Practitioner's Perspective", The Indian Economy Conference, Program on Comparative Economic Development (PCED) at Cornell University, USA.

${ }^{5}$ Narsimham Committee-I
} 
Reserve Bank of India has implemented banking sector reforms in two phases. The first reform focused on introduction of several prudential norms, major changes in the policy framework, and formation of competitive atmosphere. The second phase of reforms began in 1997 with aim to reorganization measures, human capital development, technological up-gradation, structural development which helped them for achieving universal benchmarks in terms of prudential norms and pre-eminent practices. The Financial sector reforms were undertaken in 1992 based on the recommendations of the CFS. Later, The Narsimham Committee has provided the proposal for reforming the financial sector. The committee also argued that 'economic reforms in the real sector of economy will, however, fail to realize their full potential without a parallel reform of the financial sector. It focused on several issues like, releasing of more funds to banks, deregulation in interest rates, capital adequacy, income recognition, disclosures and transparency norms etc. However, financial sector reforms focused on improving the competitive efficiency of the banking system. The financial reform process has commenced since 1991 which was made the banking sector healthy, sound, well- capitalized and become competitive.

This paper seeks to determine the impact of various market and regulatory initiatives on efficiency improvements of Indian banks. The reform process has shifted the focus of public sector dominated banking system from social banking to a more efficient and profit oriented industry. While the reform process has resulted in the private sector replacing the government as the source of resources for public sector banks (PSBs), the infusion of private equity capital has led to shareholders challenges to bureaucratic decision making. PSBs also face increasing competition not only from private and foreign banks but also from growing non-banking financial intermediaries like mutual funds and other capital market entities. The competitive pressures to improve efficiency in the banking sector has resulted in a switch from traditional paper based banking to electronic banking, use information technology and shift of emphasis from brick and mortar banking to use of ATMs. 


\section{Brief review of literature}

A few DEA-based studies of efficiency in the Indian banking system have appeared in recent years. They have used a variety of specifications for inputs and outputs as evident from Table 1. Inputs vary from purely financial such as interest and non-interest expenses to purely physical like number of branches and employees. Outputs are either income related interest or non-interest income or product/service related - loans, investments and non-interest income. Deposits appear as inputs or outputs depending upon whether the authors work with the intermediation or production interpretation of banking business. The efficiency scores were found to be relatively sensitive to the specification in terms of inputs and outputs. 
Table 1. Recent studies on efficiency of Banking system in India

\begin{tabular}{|c|c|c|c|c|c|c|}
\hline SI. & Year & Authors & Methodology & Brief Recommendations & Scope & Assessment Parameters/ Drivers \\
\hline 1. & 2008 & $\begin{array}{l}\text { Sunil KUMAR } \\
\text { \& Rachita } \\
\text { GULATI }\end{array}$ & $\begin{array}{l}\text { 1.Logistic Regression } \\
\text { Analysis } \\
\text { 2.Slacks and Targets } \\
\text { Setting Analysis } \\
\text { 3. input-oriented } \\
\text { efficiency scores }\end{array}$ & $\begin{array}{l}\text { The results of logistic regression analysis } \\
\text { provides that the factors like market share, } \\
\text { profitability, and asset quality do not } \\
\text { have any significant impact on the overall technical } \\
\text { efficiency of Indian public } \\
\text { sector banking industry. }\end{array}$ & $\begin{array}{l}\text { Technical, Pure Technical, } \\
\text { and Scale Efficiencies in } \\
\text { Indian Public Sector } \\
(1992-2005)\end{array}$ & $\begin{array}{l}\text { Outputs: } \\
\text { i) net-interest income, and } \\
\text { ii) non-interest income, } \\
\text { while input vector contains three } \\
\text { Inputs: } \\
\text { i) physical capital, } \\
\text { ii) labour, and } \\
\text { iii) loanable funds. }\end{array}$ \\
\hline 2. & 2008 & $\begin{array}{l}\text { Anthony } \\
\text { Musonda }\end{array}$ & $\begin{array}{l}\text { 1.translog stochastic } \\
\text { frontier cost function } \\
\text { 2. conditional mean (CM) } \\
\text { inefficiency model } \\
\text { 3. stochastic frontier } \\
\text { approach } \\
\text { 4.data envelopment } \\
\text { analysis (DEA) }\end{array}$ & $\begin{array}{l}\text { the efficiency gap between domestic banks and } \\
\text { foreign banks remains wide. } \\
\text { Banks continue to exhibit poor risk assessment } \\
\text { techniques as exemplified by higher loan loss } \\
\text { provisions }\end{array}$ & $\begin{array}{l}\text { DETERMINANTS OF } \\
\text { COST EFFICIENCY IN } \\
\text { THE ZAMBIAN BANKING } \\
\text { SECTOR(1998- 2006) }\end{array}$ & $\begin{array}{l}\text { 1.Labour Cost } \\
\text { 2.Funding Cost } \\
\text { 3.Capital Cost }\end{array}$ \\
\hline 3. & 2003 & $\begin{array}{l}\text { Biswa Swarup } \\
\text { Misra }\end{array}$ & $\begin{array}{l}\text { The credit output } \\
\text { dynamics has been } \\
\text { studied for three broad } \\
\text { sectors of each State viz, } \\
\text { agriculture, industry } \\
\text { and services }\end{array}$ & $\begin{array}{l}\text { improvement in the overall allocative efficiency in } \\
\text { the post reform period for the majority } \\
\text { of the States }\end{array}$ & $\begin{array}{l}\text { Allocative Efficiency of the } \\
\text { Indian Banking System in } \\
\text { the Post-Reform } \\
\text { Period: A State Level } \\
\text { Analysis(1981-1992) and } \\
(1993-2001)\end{array}$ & \\
\hline 4. & 2010 & $\begin{array}{l}\text { Subhash C. } \\
\text { Ray, } \\
\text { Abhiman Das }\end{array}$ & $\begin{array}{l}\text { Nonparametric DEA } \\
\text { methodology. } \\
\text { Nonparametric kernel } \\
\text { density } \\
\text { estimation }\end{array}$ & $\begin{array}{l}\text { Relatively high cost efficiency levels for Indian } \\
\text { banks during the post-reform period 1997-2003. } \\
\text { There is no definite evidence that privatization } \\
\text { enhances efficiency, at least in the case of Indian } \\
\text { banks }\end{array}$ & $\begin{array}{l}\text { Distribution of cost and } \\
\text { profit efficiency: Evidence } \\
\text { from Indian banking } \\
(1997-2003) \text {. }\end{array}$ & $\begin{array}{l}\text { Inputs: } \\
\text { 1.Funds, 2.Labour, 3.Capital, } \\
\text { 4.Quasi-fixed inputs } \\
\text { Outputs: } \\
\text { 5.Investments, } \\
\text { 6.Earning advances, Other income }\end{array}$ \\
\hline 5. & 2009 & $\begin{array}{l}\text { Panayiotis P. } \\
\text { Athanasoglou, } \\
\text { Evangelia A. } \\
\text { Georgiou, } \\
\text { Christos C. } \\
\text { Staikouras }\end{array}$ & $\begin{array}{l}\text { Assesses the evolution } \\
\text { of output and productivity } \\
\text { in the } \\
\text { Greek banking industry } \\
\text { for the period 1990- } \\
2006 \text {. } \\
\text { (a) the production } \\
\text { approach; } \\
\text { (b) the intermediation } \\
\text { approach; and } \\
\text { (c) the user-cost } \\
\text { approach. }\end{array}$ & $\begin{array}{l}\text { Assesses the evolution of output and productivity in } \\
\text { the Greek banking industry for the period 1990- } \\
2006 \text {. Capital and total factor productivity have also } \\
\text { improved remarkably mainly since 1999, due to the } \\
\text { structural changes that took place within the } \\
\text { industry, capital (mainly IT) investments and } \\
\text { improvement in the quality of human capital. }\end{array}$ & $\begin{array}{l}\text { Assessing output and } \\
\text { productivity growth in the } \\
\text { banking industry 1990- } \\
2006 \text {. }\end{array}$ & $\begin{array}{l}\text { 1. Three categories: financial } \\
\text { intermediation, payment services and } \\
\text { "other" services. } \\
\text { 2. the effect of labor quality on } \\
\text { productivity measurement of Greek } \\
\text { banks, } 5 \text { as well as the contribution of } \\
\text { inputs' and TFP growth to output } \\
\text { growth. }\end{array}$ \\
\hline 6. & 2001 & $\begin{array}{l}\text { Leigh Drake, } \\
\text { Maximilian }\end{array}$ & $\begin{array}{l}\text { Non-parametric frontier } \\
\text { approach, data }\end{array}$ & $\begin{array}{l}\text { Powerful size-efficiency relationships are } \\
\text { established with respect to both technical and scale }\end{array}$ & $\begin{array}{l}\text { Efficiency in Japanese } \\
\text { banking: }\end{array}$ & $\begin{array}{l}\text { 1.Total loans and bills discounted, } \\
\text { 2.Liquidasset } s \text { and other investments }\end{array}$ \\
\hline
\end{tabular}

W.P. No. 2011-03-01 Page No. 7 


\begin{tabular}{|c|c|c|c|c|c|c|}
\hline & & J.B. Hall & $\begin{array}{l}\text { envelopment analysis, to } \\
\text { analyse the technical and } \\
\text { scale efficiency in } \\
\text { Japanese banking using } \\
\text { a recent cross-section } \\
\text { sample }\end{array}$ & efficiency. & $\begin{array}{l}\text { An empirical analysis } \\
\text { (1997) }\end{array}$ & $\begin{array}{l}\text { in securities, } \\
\text { 3.Other income; } \\
1 \text { General and } \\
\text { administrative expenses, } \\
\text { 2.Fixed assets (premises and } \\
\text { equipment), } \\
3 \text { Retail and wholesale deposits. }\end{array}$ \\
\hline 7. & 2010 & $\begin{array}{l}\text { Santosh } \\
\text { Kumar Das }\end{array}$ & $\begin{array}{l}\text { Stochastic Frontier } \\
\text { Approach (cost frontier) } \\
\text { and RBI data for } \\
60 \text { Indian commercial } \\
\text { banks and on the basis } \\
\text { of empirical investigation } \\
\text { (panel estimation), the }\end{array}$ & $\begin{array}{l}\text { 1.after financial liberalization there has been no } \\
\text { significant change in the cost efficiency of the } \\
\text { public sector banks } \\
\text { 2. the domestic private banks are becoming more } \\
\text { efficient in comparison to the public sector and the } \\
\text { foreign banks }\end{array}$ & $\begin{array}{l}\text { Financial Liberalization } \\
\text { and Banking Sector } \\
\text { Efficiency: The } \\
\text { Indian Experience (1980- } \\
\text { 2007) }\end{array}$ & $\begin{array}{l}\text { Input: } \\
\text { 1.interest cost, } \\
\text { 2.labor cost and } \\
\text { 3.capital cost } \\
\text { Output: } \\
\text { 1.total loans, } \\
\text { 2.investment in securities and } \\
\text { 3.other investments }\end{array}$ \\
\hline 8. & 2009 & $\begin{array}{l}\text { Abhiman Das } \\
\text { \& Saibal } \\
\text { Ghosh }\end{array}$ & $\begin{array}{l}\text { 1.Non-parametric DEA } \\
\text { methodology } \\
\text { 2.Univariate analysis and } \\
\text { determinants of } \\
\text { inefficiency }\end{array}$ & $\begin{array}{l}\text { indicate high levels of efficiency in costs and lower } \\
\text { levels in profits, reflecting the importance of } \\
\text { inefficiencies on the revenue side of banking } \\
\text { activity, The proximate determinants of profit } \\
\text { efficiency appear to suggest that big state-owned } \\
\text { banks performed reasonably well and are more } \\
\text { likely to operate at higher levels of profit efficiency. } \\
\text { A close relationship is observed between efficiency } \\
\text { and soundness as determined by bank's capital } \\
\text { adequacy ratio. }\end{array}$ & $\begin{array}{l}\text { Financial Deregulation } \\
\text { and Profit Efficiency: } \\
\text { A Non-parametric } \\
\text { Analysis of Indian Banks } \\
(1992-2004)\end{array}$ & $\begin{array}{l}\text { Input: } \\
\text { 1.deposits, } \\
\text { 2.number of employees, 3.fixed } \\
\text { assets and } \\
\text { 4.equity } \\
\text { Output: three measures- } \\
\text { 1.investments, } \\
\text { 2.loans and } \\
\text { 3. advances and other non-interest } \\
\text { fee based incomes. }\end{array}$ \\
\hline 9. & 2006 & $\begin{array}{l}\text { Abhiman Das } \\
\text { \& Saibal } \\
\text { Ghosh }\end{array}$ & $\begin{array}{l}\text { 1. Nonparametric Data } \\
\text { Envelopment Analysis } \\
\text { (DEA). } \\
\text { 2.Three different } \\
\text { approaches viz., } \\
\text { intermediation approach, } \\
\text { value-added approach } \\
\text { and operating approach } \\
\text { have been employed to } \\
\text { differentiate how efficiency } \\
\text { scores vary with changes } \\
\text { in inputs and outputs }\end{array}$ & $\begin{array}{l}\text { 1. Results suggest a large asymmetry between } \\
\text { banks regarding their technical efficiency over the } \\
\text { years. } \\
\text { 2. Technical efficiency estimates were found to be } \\
\text { higher under value-added approach than under the } \\
\text { intermediation approach. Under the latter approach, } \\
\text { Indian banks were marked with relatively low level } \\
\text { of technical efficiency and there was a persistent } \\
\text { but apparently declining trend in technical efficiency }\end{array}$ & $\begin{array}{l}\text { Financial deregulation and } \\
\text { efficiency: An empirical } \\
\text { analysis of Indian banks } \\
\text { during the post reform } \\
\text { period (1992-2002) }\end{array}$ & $\begin{array}{l}\text { Variables: } \\
\text { 1.bank size, } \\
\text { 2.ownership, } \\
\text { 3.capital } \\
\text { 4.adequacy ratio, } \\
\text { 5.non-performing loans and } \\
\text { 6.management quality }\end{array}$ \\
\hline
\end{tabular}




\section{Specification of model}

Data Envelopment Analysis (DEA) was used to identify banks that are on the output frontier given the various inputs at their disposal. Efficiency of each institution is then derived relative to the best-practice bank on the frontier that uses a comparable mix of inputs. Efficiency of firm is measured in terms of its relative performance that is, efficiency of a firm relative to the efficiencies of firms in a sample. A formal econometric approach for estimating relative efficiency is with reference to the "best practice frontier". Best practice frontier, a term originally coined by Farrell (1957) denotes maximum output that can be obtained with a given set of input quantities for a given set of firms in a sample. He also proposed that the efficiency of a firm consists of two components: technical efficiency, which reflects the ability of a firm to obtain maximum output from a given set of inputs, and allocative efficiency, which reflects the ability of a firm to use the inputs in optimal proportions, given their respective prices and the production technology. These two measures are then combined to provide a measure of total economic efficiency. The output and input perspective will coincide when measuring technical efficiency under Constant-Return-to-Scale (CRS). The allocative and economic efficiency measures however are completely different in nature and are not likely to coincide for other reasons than by chance.

Data Envelopment Analysis (DEA) involves the use of linear programming methods to construct a non-parametric piecewise surface (or frontier) over the data, so as to be able to calculate efficiencies relative to this surface. More detailed reviews of the DEA methodology were also presented by Seiford and Thrall (1990), Lovell (1993), Ali and Seiford (1993), Lovell (1994), Charnes et al (1995) and Seiford (1996). 
Consider ' $n$ ' firms producing ' $m$ ' different outputs using ' $h$ ' different inputs. Thus, $Y$ is an $m^{*} n$ matrix of outputs and $X$ is an $h^{*} n$ matrix of inputs. Both matrices contain data for all ' $n$ ' firms. The technical efficiency (TE) measure under the assumption of constant returns to scale (CRS) can be formulated as follows:

$\operatorname{Min} \theta, \lambda \theta$

Subject to $-y_{i}+Y \lambda \sqcap 0$,

$$
\theta x_{i}-X \lambda \sqcap 0
$$

$\lambda \sqcap 0$

$\theta \varepsilon(0,1]$

and solved for each firm in the sample. $\theta_{i}$ is firm i's index of technical efficiency relative to the other firms in the sample. $y_{i}$ and $x_{i}$ represents the output and input of firm ' $i$ ' respectively. $Y \lambda$ and $X \lambda$ are the efficient projections on the frontier. A measure of $\theta_{i}=1$ indicates that the firm is completely technically efficient. Thus, $1-\theta_{i}$ measures how much firm i's inputs can be proportionally reduced without any loss in output.

However, the assumption of CRS is correct only as long as firms are operating at an optimal scale (Coelli et al, 2002). Various constraints on inputs like financing and the goals of the farmer may cause the firm to operate at a non-optimal scale. Using the CRS-DEA model when firms are not operating at their optimal scale will cause the TEmeasures to be influenced by scale efficiencies and thus the measure of technical efficiency will be incorrect. By adding a convexity constraint to the model above variable returns to scale (VRS) is instead assumed:

$\operatorname{Min} \theta, \lambda \theta$

Subject to $-y_{i}+Y \lambda \square 0$,

$\theta x_{i}-X \lambda \sqcap 0$,

$N 1^{\prime} \lambda=1$

$\lambda \sqcap 0$

$\theta \varepsilon(0,1]$ 
The new constraint is $N 1^{\prime} \lambda=1$ where $N 1$ is a $n^{*} 1$ vector of ones. This constraint makes the comparison of firms of similar size possible, by forming a convex hull of intersecting planes, so that the data is enveloped more tightly. The technical efficiency measures under VRS (Pure TE) will always be at least as great as under the CRS-assumption.

Many studies have decomposed the TE scores obtained from a CRS DEA into two components, one due to scale inefficiency and one due to "pure" technical efficiency. If there is a difference in the two TE scores for a particular DMU, then this indicates that the DMU has scale inefficiency and that the scale inefficiency can be calculated from the differences between the TE $E_{V R S}$ score and the TE $E_{C R S}$ score (Coelli, 2006).

\section{$T E_{C R S}=T E_{V R S} \times S E$}

However, the present study is confined only to the CRS assumption of DMUs. We did not use the VRS assumption for estimating the efficiency. Each observation included two outputs i.e., loans/advances $\left(Y_{1}\right)$ per unit per annum and non-interest income $\left(Y_{2}\right)$ per unit per annum. In the input category, three variables were included. They were no.of branches $\left(X_{1}\right)$, total operating expenses per annum $\left(X_{2}\right)$ and deposits $(X 3)$. The DEA model was estimated using DEAP 2.0 algorithm (Coelli, 1996).

While inputs and outputs are easily identified in most businesses, that is hardly the case in banking. At the heart is the question of whether deposits are input or output. A typical financial intermediation role for banks involves the use of deposits together with physical inputs of land, labor and capital to make loans and earn interest income. Banks also recognize the importance of generating non-interest income as an anti-dote to the variability in interest income. This approach suggests that we should treat the number of bank branches, total operating expenses and deposits as inputs and loans (advances) and non-interest income as outputs. In this formulation, deposits are not coveted as an independent output; instead they are treated only as a conduit to generating loans. In most banking systems, bank investments (in addition to loans) are also considered as a legitimate output. But such investments in India are mostly in government securities which are often thought of as reflections of "lazy" banking. According to this line of thinking, higher investments simply imply that banks are not pushing loans adequately. 
In view of this, we do not use investments as banks' output. For the present study data from 2005 to 2010 was used for the analysis. These results are based on data from the Performance of Indian Banks by the Association of Indian Banks and the Banking Statistics and Annual Reports of the Reserve Bank of India (RBI).

\section{Results and Discussions}

The technical efficiencies of sample banking units under CRS models of DEA approach is presented in table 2. All banks estimated mean technical under DEA-CRS model were 95.6 per cent in 2005 and move up to 97.9 per cent in 2010. In terms of technical efficiency, most of the sample units showed more than 90 per cent efficiency.

Table 2 Efficiency of different banking units

\begin{tabular}{|l|c|c|c|c|c|}
\hline \multicolumn{1}{|c|}{ Type } & $\mathbf{2 0 0 5 - 0 6}$ & $\mathbf{2 0 0 6 - 0 7}$ & $\mathbf{2 0 0 7 - 0 8}$ & $\mathbf{2 0 0 8 - 0 9}$ & $\mathbf{2 0 0 9 - 1 0}$ \\
\hline State-owned banks & 0.904 & 1.000 & 1.000 & 1.000 & 1.000 \\
\hline National Banks & 1.000 & 1.000 & 1.000 & 1.000 & 1.000 \\
\hline $\begin{array}{l}\text { Total - public } \\
\text { sector banks }\end{array}$ & 0.966 & 1.000 & 1.000 & 1.000 & 1.000 \\
\hline Old-private banks & 0.934 & 0.936 & 0.924 & 0.878 & 0.889 \\
\hline New-private banks & 1.000 & 1.000 & 1.000 & 1.000 & 1.000 \\
\hline Total private banks & 0.982 & 0.986 & 0.984 & 0.972 & 0.972 \\
\hline Foreign banks & 1.000 & 1.000 & 1.000 & 1.000 & 1.000 \\
\hline All-banks & 0.956 & 0.986 & 0.996 & 0.994 & 0.979 \\
\hline
\end{tabular}

It is concluded from the table that the national banks, new private banks and foreign banks have showed high efficiency over a period time than remaining banks. They are all performed equally in relative terms. The units under state-owned banks, total-public sector banks and old private banks have improved their efficiency in the recent times when compared to 2005 status. The scheduled commercial banks together improved their efficiency continuously up to 2007-08 and after there was a slight decline in the last two subsequent years. 
In general, the efficiency scores were improved among all the scheduled commercial bank types when compared with earlier research studies. Further scrutiny of these results is needed by bank-wise to get better understanding of them. Similarly, identification of factors for enhancing the efficiency could also be analyzed. The variables influencing the bank efficiency negatively could also be identified. This comprehensive assessment will bring better clarity about the efficiency in Indian banking system. 


\section{References}

Coelli T. (1995): "Recent developments in frontier modeling and efficiency measurement, Australian Journal of Agricultural Economics, Vol.39, Pp: 219-245

Coelli, T., P.D.S Rao and G.E Battese (2002): "An Introduction to Efficiency and Productivity Analysis", (London: Kluwer Academic Publishers).

Coelli, T.J., (1996): "A Guide to DEAP 2.1: A Data Envelopment Analysis Computer Program", CEPA working paper No.8/96, ISBN 1863894969, Department of Econometrics, University of New England, Pp: 1-49.

Das, Abhiman \& Gosh, Saibal (2006): "Financial Deregulation and Efficiency: An empirical analysis of Indian Banking during the Post-Reform Period", Review of Financial Economics, 15, Pp:193-221.

Das, Abhiman \& Gosh, Saibal (2009): "Financial Deregulation and Profit Efficiency: A Non-Parametric Analysis of Indian Banks", Munich Personal RePEc Archive. Das, S.K.(2010): "Financial Liberalization and Banking Sector Efficiency: The Indian Experience", $12^{\text {th }}$ Money and Finance Conference, $11-12^{\text {th }}$ March IGIDR, Mumbai (India).

Farrell, M.J (1957): “Generalized Farrell Measures of Efficiency: An application to Milk processing in Swedish Dairy plants”, Economic Journal, Vol no.89, Pp: 294-315.

Kumar, S., Gulati, R., (2008): "An Examination of Technical, Pure Technical and Scale Efficiency in Indian Publick Sector Banks using Data Envelopment Analysis", Eurasian Journal of Business and Economics, Vol.1 (2), Pp:33-69.

Leigh, D. \& Hall, J.B.(2003): "Efficiency in Japanese Banking: An Empirical Analysis", Journal of Banking \& Finance, 27, Pp:891-917.

Lovell, C.A.K (1993): "Production Frontiers and Productive Efficiency" in H.O Fried; C.A.K Lovell and S.S Schmidt (ed.) The Measurement of Productive Efficiency, (New York: Oxford University Press), Pp: 3-67. 
Mishra, B.S.(2003): "Allocative Efficiency of the Indian Banking System in the PostReform Period- A State Level Analysis", Reserve Bank of India Occasional Paper, Vol.24, No.3, Winter.

Musonde, Anthony (2008): An Investigation Into the Determinants of Cost Efficiency in the Zambian Banking Sector", $13^{\text {th }}$ Annual African Econometric Society Conference, 9-11 July.

Panayiotis, P. et al. (2009): "Assessing output and productivity growth in Banking Industry", A Quarterly Review of Economics and Finance, 49, Pp:1317-1340.

Ram Mohan T. T. (2002), "Deregulation and Performance of Public Sector Banks", Economic and Political weekly", Vol. 37, pp. 393.

Ram Mohan T. T. \& Subhash C. Ray (2004)Comparing Performance of Public and Private Sector Banks: A Revenue Maximisation Efficiency Approach", Economic and Political weekly, Vol.39, No-12, Pp:1271-1276.

Seiford, L.M and R.M Thrall (1990): "Recent Developments in DEA: The Mathematical Programming Approach to Frontier Analysis", Journal of Econometrics, 46, Pp: 738, North Holland.

Subhass, C.Ray \& Abhiman Das (2010): "Distribution of Cost and Profit efficiency: Evidence from Indian Banking", European Journal of Operational Research, 201, Pp: 297-307. 